\title{
AMASSEDS: AN INTERDISCIPLINARY INVESTIGATION OF A COMPLEX COASTAL ENVIRONMENT
}

By Charles A. Nittrouer, David J. DeMaster, Alberto G. Figueiredo and James M. Rine

A MULTIDISCIPLINARY Amazon Shelf SEDiment Study (AmasSeds) is being undertaken on the continental shelf near the mouth of the Amazon River. Details of the AmasSeds international research project are described in the five papers which follow. The present paper outlines the justification, background and approach of the overall project.

On the Amazon shelf, between the Pará estuary and the Brazil-French Guiana Border (Fig. 1), material input (water, solutes, particulates) and energy expenditure (tides, currents, winds, waves) are enormous. This situation produces a myriad of complex interdependent oceanic processes. Sediment is a common link between the diverse processes, because most of them affect and/or are affected by the particles found on the Amazon shelf.

The fundamental justification for AmasSeds research is that a number of unique oceanic processes are active near the mouths of very large rivers (e.g., Amazon, Huanghe, Changjiang, Ganges-Brahmaputra), and that these processes cannot be understood solely by extrapolation from observations of smaller river systems. For example, the papers which follow will demonstrate that biological productivity (pelagic and benthic) and cycling of many geochemical components (inorganic and organic) are largely controlled by the immense discharge of sediment particles. The freshwater discharge of the Amazon displaces typical estuarine circulation from the river mouth into the three-dimensional setting of the shelf, where it is superimposed on marine circulation. Extremely high supply rates of sediment to the Amazon shelf create fluid muds (concentrations $>10 \mathrm{~g} \mathrm{l}^{-1}$ ) which severely affect marine sediment

C.A. Nittrouer and J.M. Rine, Marine Sciences Research Center, State University of New York. Stony Brook, NY, 11794, USA. D.J. DeMaster, Department of Marine, Earth and Atmospheric Sciences, North Carolina State University, Raleigh, NC, 27695, USA. A.G. Figueiredo, Departamento de Geologia. Universidade Federal Fluminense, Niteroi, RJ, 24260, Brazil. transport and create an extensive subaqueous delta with special morphologic and stratigraphic character.

In addition to being unique, oceanic processes in coastal environments near the mouths of large rivers are very important. They control the fate of the material that is discharged, and in this way affect global budgets. On a worldwide basis, the Amazon discharges $18 \%$ of all river water (Oltman, 1968), 10\% of fluvial sediment (Milliman and Meade, 1983; Meade et al., 1985), and 8\% of dissolved solids (Livingstone, 1963; Gibbs, 1972). How and whether this material reaches the rest of the world ocean is dependent upon oceanic processes operating on the Amazon shelf.

AmasSeds also will provide valuable new insights into some special attributes of the Amazon shelf, such as its location in an equatorial setting. Terrestrial and marine equatorial environments are especially sensitive to world climatic conditions, and the strata preserved at the mouth of the Amazon record the histories of both environments. Chemical weathering in equatorial settings produces lateritic soils and iron-rich sediments, which cause unusual geochemical signatures in the marine portions of the Amazon dispersal system. In addition, important changes to the basic physics of ocean circulation result when river effluent is released at the equator in the absence of Coriolis forces.

The Amazon shelf is an ideal study area to investigate the detailed operation of interdisciplinary oceanic processes for reasons described above, and because results from previous research allowed the design of an intricate field and laboratory study.

\section{The Amazon Shelf}

This section briefly describes knowledge of the Amazon shelf which has been gained from previous research. A thorough summary is presented in Nittrouer and DeMaster (1986).

The Amazon dispersal system stretches for about $5000 \mathrm{~km}$ from the Andes mountains to the Caribbean Sea during high stands of sea level and
... a number of unique

oceanic processes are active near the mouths of very large rivers... 


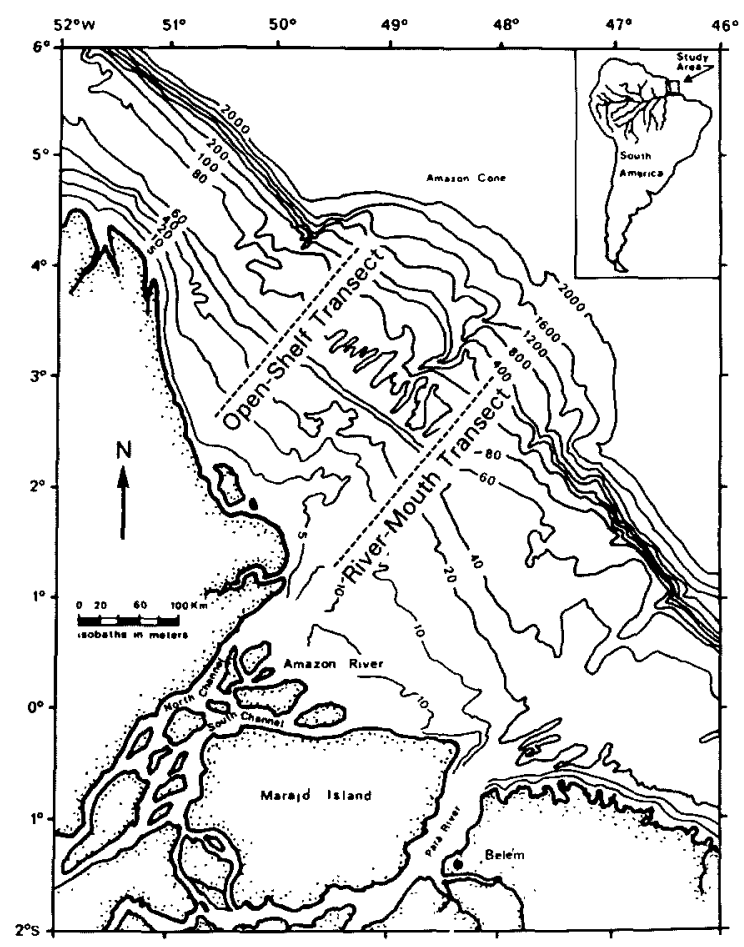

Fig. 1: Bathymetric chart of the Amazon continental shelf. Although sampling and measurements cover most of the shelf, the research groups focus their observations on the River-Mouth and Open-Shelf Transects.

to the Mid-Atlantic Ridge during low stands of sea level. The Andes were uplifted in the Miocene, creating the primary source of dissolved and particulate material to the river (Gibbs, 1967). The large size and equatorial location minimize fluctuations in Amazon discharge. Figure 2 shows that water discharge rises to a maximum in May/June and falls to a minimum in October/November. Although dissolved solids probably mimic this pattern, complexities of the drainage basin cause highs and lows in sediment discharge to precede those of water by a couple months (Meade $e t$ al., 1985). Tidal effects on the Amazon propagate 800 $\mathrm{km}$ upstream to the town of Obidos, and little research regarding discharge has been done between there and the river mouth. Therefore, estimates of discharge to the ocean (presented in the previous section) have some uncertainty.

The freshwater discharge of the Amazon enters a very energetic environment. The immense discharge itself causes estuarine-like circulation on the shelf to bring bottom water landward (Gibbs, 1970). Tidal currents routinely exceed $1 \mathrm{~m} \mathrm{~s}^{-1}$ and have a strong across-shelf component (Gibbs, 1982; Curtin, 1986b). The North Brazil Current (NBC) flows northwestward, sweeping the outershelf and upper slope with speeds also exceeding $1 \mathrm{~m} \mathrm{~s}^{-1}$ (Flagg et al., 1986; Richardson and Reverdin, 1987). This current can undergo eastward retroflexion during some months of the year (Fig. 3). Easterly trade winds blow continuously, with wind stresses which can exceed $1 \mathrm{dyn} \mathrm{cm}^{-2}$ (Picaut et al., 1985) and which maintain surface gravity waves. The Amazon River discharge, the NBC, and the trade winds all exhibit strong seasonal fluctuations (Fig. 3). The net effect is to mix and advect Amazon water with variable intensity, and to form a plume of identifiable water which extends for hundreds of kilometers seaward and northwestward from the river mouth (Milliman et al., 1975a; Curtin, 1986a; Muller-Karger et al., 1988).

Dissolved chemical species are supplied to the waters of the Amazon shelf: in solution with river water, by release from river-borne particulates, and with open-ocean water driven by the landward-flowing bottom currents. Inorganic removal onto particulates (Sholkovitz et al., 1978; DeMaster et al., 1986) and biological uptake by primary productivity (Sholkovitz and Price, 1980; Milliman and Boyle, 1975) are important geochemical processes on the Amazon shelf, and both are controlled by the transport and settling of suspended sediment. In the seabed, diagenetic redox reactions (controlled by $\mathrm{Fe}$ and $\mathrm{Mn}$ oxides) and intense physical reworking can release particlebound species (Aller et al., 1986; McKee et al., 1987). Turbidity restrictions on biological productivity and subsequent degradation reduce the

Total Discharge to Ocean

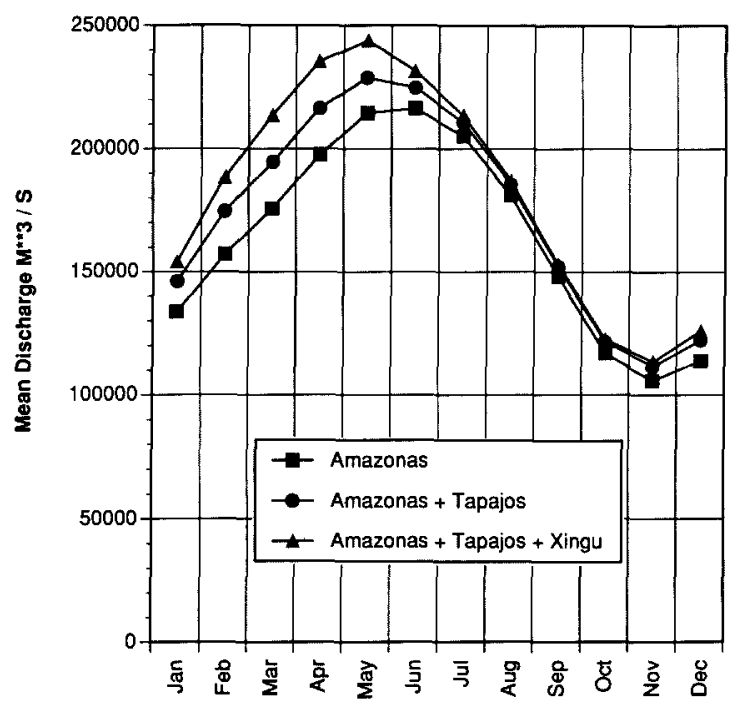

Fig. 2: Discharge of freshwater from the Amazon River to the ocean. These curves were assembled from monthly means for the period 1968-1987 (data supplied by the Brazilian Agency DNAEE). The Amazonas data were collected at Obidos. The Tapajos and Xingu Rivers are the two primary tributaries which enter the Amazon River seaward of Obidos. 


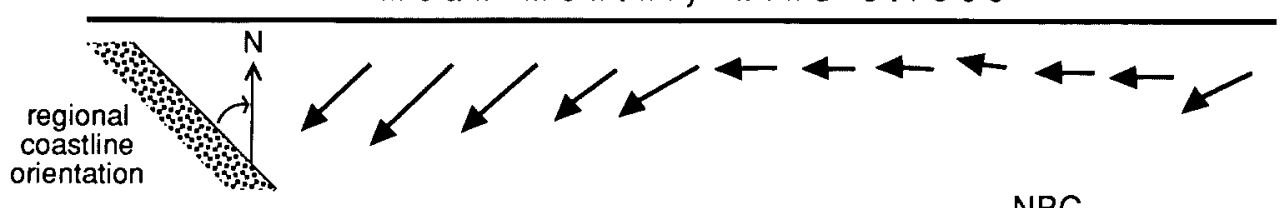

NBC retroflexion

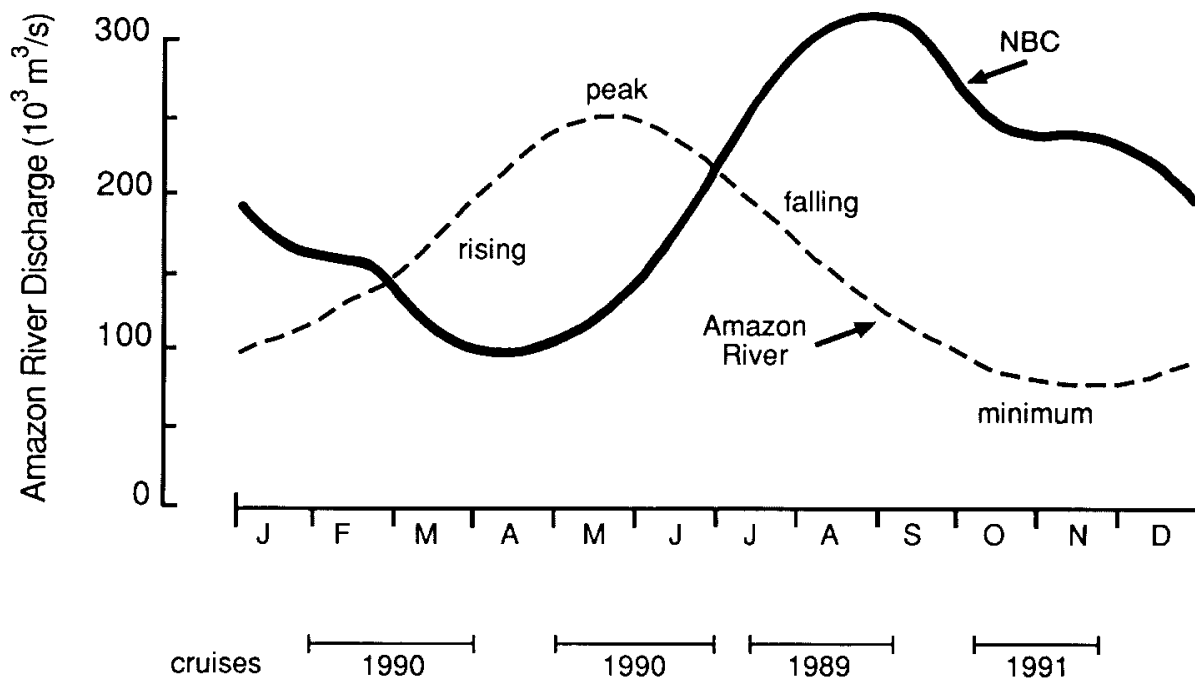

Fig. 3: Timeline for AmasSeds research cruises and for the primary physical processes affecting the Amazon shelf. The peak wind stress occurring in February is about 1.1 dyn $\mathrm{cm}^{-2}$ (Picaut et al., 1985). The flow of the North Brazil Current (NBC) (Philander and Pacanowski, 1986) is given in sverdrups $\left(10^{6} \mathrm{~m}^{3} \mathrm{~s}^{-1}\right)$. The current flows northwestward along the coast, but retroflects eastward during part of the year.

preservation of biogenic materials. Only minor amounts of marine carbon (Showers and Angle, 1986) and biogenic silica (DeMaster et al., 1983) are being buried in the seabed between shore and about the 40-m isobath.

The physical processes operating on the Amazon shelf produce large shear stresses, which advect suspended sediment northwestward and maintain high concentrations in surface $(>10 \mathrm{mg}$ $\left.1^{-1}\right)$ and bottom (>100 $\left.\mathrm{mg}^{-1}\right)$ waters, seaward to at least the 30-m isobath (Nittrouer et al., 1986a). The seabed surface of the Amazon shelf is dominated by modern mud from shore to about the 60-m isobath, and by exposure of a transgressive sand layer farther seaward to the shelf break (Barreto et al., 1975; Nittrouer et al., 1983). The mud has formed a subaqueous delta with gently dipping topset strata ( $0-40 \mathrm{~m}$ water depth), steeply dipping foreset strata $(40-60 \mathrm{~m})$, and thin bottomset strata at the base (Figueiredo et al., 1972; Alexander $e t$ al.. 1986; Nittrouer et al., 1986b). The diverse range of energetic physical processes active on the Amazon shelf.created many questions about the extent of the present accumulation of mud (Milliman et al., 1975b; Gibbs, 1976; Kuehl et al., 1982). Approximately two-thirds of the river discharge is accumulating on the Amazon shelf, however, little or no accumulation is occurring on the inner shelf in less than about $15 \mathrm{~m}$ water depth or northward between $4^{\circ} \mathrm{N}$ and $5^{\circ} \mathrm{N}$ (Kuehl et al., 1986).

\section{The Approach to AmasSeds Research}

AmasSeds is divided into five disciplinary groups, however, the prevailing attribute of AmasSeds is its interdisciplinary character. The view of the AmasSeds project is that oceanic processes on the Amazon shelf resemble a complex jigsaw puzzle with many interlocking processes. Any one process can be observed and described, but its operation and significance cannot be understood fully without examining its relationship to other processes. The five groups are described in the following articles; they include: physical oceanography, water-column geochemistry (including primary productivity), sediment transport, diagenetic chemistry and associated benthic biology, and sedimentology/stratigraphy.

AmasSeds is a fully integrated international project. Scientists from Brazil and the United States worked together for several years planning AmasSeds. They participated side-by-side in the field work on the R/V ISELIN, and now they are cooperating with laboratory research. The project includes exchange of faculty and students, as well as presentation of symposia at national meetings
The view of the

AmasSeds project is that oceanic processes on the Amazon shelf resemble a complex jigsaw puzzle with many interlocking processes. 
... the overriding

scientific theme is the

association of

sediment particles with

the oceanic processes. in each country. In addition to the participants listed on the following five papers, many other Brazilian, US and international scientists are performing related research. A total of about $150 \mathrm{sci-}$ entists have been involved to date.

In order to focus the efforts of such a large group of investigators, common themes and sampling stations have been identified. As stated previously, the overriding scientific theme is the association of sediment particles with the oceanic processes. Two transects have been identified (Fig. 1), one near the river mouth and the other on the open shelf to the north. In addition to observations at other diverse locations on the shelf, all research groups have focussed on these two transects. This approach allows direct comparisons between the various data sets.

The Amazon shelf is a remote and complex area. Previous studies have involved reconnaissance-type field expeditions, which have recovered various "snap-shots" of the processes operating. However, the driving forces on the Amazon shelf (e.g., river discharge, wind stress, NBC strength) reveal distinct temporal variations (Fig. 3), and a comprehensive understanding of the oceanic processes requires time-series studies on various time scales. AmasSeds involves four research cruises under diverse environmental conditions. Each cruise is for a duration of about two months, and many stations (especially on the River-Mouth and Open-Shelf Transects) are reoccupied during this period. The cruises contain anchor stations of about 24-h duration, and reoccupation of the anchor stations on fortnightly and seasonal time scales. In this way processes fluctuating on diurnal to seasonal time scales can be investigated.

Each cruise is divided into a number of legs, based on similar sampling needs of participants. Each leg contains Brazilian and US scientists representing a blend of disciplines. The first three cruises have been completed (Fig. 3), and the fourth is scheduled for October-November 1991 . Laboratory work and synthesis of AmasSeds research will not be completed until 1993. However, many new discoveries already have been made and should be disseminated to the oceanographic community. This is the purpose of the present and the accompanying papers.

\section{Acknowledgements}

AmasSeds support for participation of US scientists and for use of the research vessel ISELIN comes from the National Science Foundation. Brazilian scientists are supported by Conselho Nacional de Desenvolvimento Científico e Tecnológico and Comissão Interministerial para os Recursos do Mar.

References

Aller, R.C., J.E. Mackin and R.T. Cox, 1986: Diagenesis of $\mathrm{Fe}$ and $\mathrm{S}$ in Amazon inner shelf muds: apparent dom- inance of $\mathrm{Fe}$ reduction and implications for the genesis of ironstones. Cont. Shelf Res., 6, 263-289.

Alexander, C.R., C.A. Nittrouer and D.J. DeMaster. 1986: High-resolution seismic stratigraphy and its sedimentological interpretation on the Amazon continental shelf. Cont. Shelf Res., 6, 337-357.

Barreto, L.A.. J.D. Milliman, C.A.B. Amaral and O. Francisconi, 1975: Upper continental margin sedimentation off Brazil: northern Brazil. Contrib. Sedimentol. 4, $11-$ 43.

Curtin, T.B., 1986a: Physical observations in the plume region of the Amazon River during peak discharge-II. water masses. Cont. Shelf Res., 6, 53-71.

, 1986b: Physical observations in the plume region of the Amazon River during peak discharge-III. currents. Cont. Shelf Res., 6, 73-86.

DeMaster, D.J., G.B. Knapp and C.A. Nittrouer, 1983: Biological uptake and accumulation of silica on the Amazon continental shelf. Geochim. Cosmochim. Acta. 47, 1713-1723.

, S.A. Kuehl and C.A. Nittrouer, 1986: Effects of suspended sediments on geochemical processes near the mouth of the Amazon River: examination of biological silica uptake and the fate of particle-reactive elements. Cont. Shelf Res., 6, 107-125.

Figueiredo, A.G., L.A.P. Gamboa, M. Gorini and E. Costa Alves. 1972: Natureza da sedimentacao atual do Rio Amazonas-testemuhos e geomorfologia submarina, (canyon) Amazonas testemuhos submarinos. Congr. Bras. Geol., 2, 51-56.

Flagg, C.N., R.L. Gordon and S. McDowell, 1986: Hydrographic and current observations on the continental slope and shelf in the western Equatorial Atlantic. Jour. Phys. Oceanogr., 16, 1412-1429.

Gibbs, R.J., 1967: The geochemistry of the Amazon River system: part I. The factors that control the salinity and the composition and concentration of the suspended solids. Geol. Soc. Am. Bull., 78, 1203-1232.

, 1970: Circulation in the Amazon River estuary and adjacent Atlantic Ocean. Jour. Mar. Res., 28, 113-123. 1972: Water chemistry of the Amazon River. Geochim. Cosmochim. Acta, 36, 1061-1066.

, 1976: Amazon River sediment transport in the Atlantic Ocean. Geology: 4, 45-48.

, 1982: Currents on the shelf of North-eastern South America. Estuar., Coast. Shelf Sci., 14, 283-299.

Kuehl, S.A., D.J. DeMaster and C.A. Nittrouer, 1986: Nature of sediment accumulation on the Amazon continental shelf. Cont. Shelf Res., 6, 209-225.

, C.A. Nittrouer and D.J. DeMaster, 1982: Modern sediment accumulation and strata formation on the Amazon continental shelf. Mar. Geol., 49, 279-300.

Livingstone, D.A., 1963: Chemical composition of rivers and lakes. U.S. Geological Survey, Prof. Paper 440G, 63 pp.

McKee, B.A., D.J. DeMaster and C.A. Nittrouer, 1987: Uranium geochemistry on the Amazon shelf: evidence for uranium release from bottom sediments. Geochim. Cosmochim. Acta, 51, 2779-2786.

Meade, R.H., T. Dunne, J.E. Richey, U. de M. Santos and E. Salati, 1985: Storage and remobilization of suspended sediment in the lower Amazon River of Brazil. Science, $228,488-490$.

Milliman, J.D. and E. Boyle, 1975: Biological uptake of dissolved silica in the Amazon River estuary. Science, 189. 995-997.

and R.H. Meade, 1983: World-wide delivery of river sediment to the oceans. Jour. Geol., 91, 1-21.

, C.P. Summerhayes and H.T. Barretto, 1975a: Oceanography and suspended matter off the Amazon River, February-March 1973. Jour. Sed. Petrol., 45, 189-206.

, C.P. Summerhayes and H.T. Barretto, 1975b: Qua- 
ternary sedimentation on the Amazon continental margin: a model. Geol. Soc. Am. Bull., 86, 610-614.

Muller-Karger. F.E.. C.R. McClain, and P.L. Richardson, 1988: The dispersal of the Amazon's water. Nature, 333, 5669.

Nittrouer, C.A., T.B. Curtin and D.J. DeMaster, 1986a: Concentration and flux of suspended sediment on the Amazon continental shelf. Cont. Shelf Res., 6. 151174.

and D.J. DeMaster, 1986: Sedimentary processes on the Amazon continental shelf: past, present and future research. Cont. Shelf Res., 6, 5-30.

, S.A. Kuehl. D.J. DeMaster, and R.O. Kowsmann. 1986b: The deltaic nature of Amazon shelf sedimentation. Geol. Soc. Am. Bull. 97. 444-458.

, M.T. Sharara. D.J. DeMaster, 1983: Variations of sediment texture on the Amazon continental shelf. Jour. Sed. Petrol., 53, 179-191.

Oltman, R.E., 1968: Reconnaissance investigations of the discharge and water quality of the Amazon River. U.S. Geological Survey. Circular 552, $16 \mathrm{pp}$.
Picaut, J., J. Servain, P. Lecompte, M. Seva, S. Lukas and G. Rougier, 1985: Climatic Atlas of the Tropical Atlantic Wind Stress and Sea Surface Temperature, 1964-1979. Universite de Bretagne Occidentale, $467 \mathrm{pp}$.

Philander, S.G.H. and R.C. Pacanowski, 1986: The mass and heat budget in a model of the tropical Atlantic Ocean. Jour. Geophys. Res., 91, 14212-14220.

Richardson, P.L. and G. Reverdin, 1987: Seasonal cycle of velocity in the Atlantic North Equatorial Undercurrent as measured by surface drifters, current meters, and shipdrifts. Jour. Geophys. Res., 92, 3691-3708.

Sholkovitz, E.R., E.A. Boyle and N.B. Price, 1978: The removal of dissolved humic acids and iron during estuarine mixing. Earth Planet. Sci. Lett., 41, 77-86.

and N.B. Price, 1980: The major-element chemistry of suspended matter in the Amazon estuary. Geochim. Cosmochim. Acta, 44, 163-171.

Showers, W.J. and D.G. Angle, 1986: Stable isotopic characterization of organic carbon accumulation on the Amazon continental shelf. Cont. Shelf Res., 6, 227-244. 